\title{
Noziedzīga nodarījuma motīvs kriminoloǵijas un krimināltiesību kontekstā
}

\author{
Aldona Kipāne \\ Rīgas Stradiṇa universitāte, Juridiskā fakultāte, Latvija \\ aldonakipane@inbox.lv
}

\section{Kopsavilkums}

Pētījuma mērḳis ir parādīt saistību starp noziedzīga nodarījuma motīva kriminologiskajām un krimināltiesiskajām - saturiskajām un konstruktīvajām - īpatnībām. Šāds pētījums ir aktuāls un būtisks, jo atspoguḷo noziedzīga nodarījuma mehānisma elementus un noziedzīga nodarījuma motīva nozīmi šajā mehānismā.

Uzskatu, ka personas psihiskā darbība, sākot ar nodoma par noziedzīga nodarījuma izdarīšanu rašanās brīdi līdz pat tā realizācijai, iedalāma atsevišḳos un atškirīgos posmos, lai gan tā ir personas psihiskās darbības īstenošanas vienots process, kas rezumējas realitātē - noziedzīga nodarījuma izdarīšanā.

Atslēgvārdi: mērḳis, motīvs, motivācija, noziedzīgs nodarījums.

\section{levads}

Cilvēks ir saprātīga būtne (latīṇu val. homo sapiens - saprātīgais cilvēks), tātad vin,am piemìt spēja domāt. Katra cilvēka mērḳtiecīga darbỉba ir prāta kontrolēta un koordinēta, savu gribu cilvēks ìsteno ar prāta kontrolētu darbību. Cilvēka uzvedība, kā zināms, ir l̦oti daudzveidīga. Lai apmierinātu savas vajadzības, cilvēks rīkojas. Personas vajadzības var būt dažādas - intelektuālas, morālas, estētiskas u. tml. Ievērojamais krievu psihologs Aleksejs L Leontjevs (А. А. Аеонтьев) uzskata, ka galveno darbības līmeni raksturo tieši motìvs, ko nosaka vajadzība. Motìvs tiek skaidrots kā darbības galvenā un veicinošā struktūra, kas, veidojot darbības priekšmetu, virza cilvēka aktivitāti.

Motīvus parasti iedala:

- pēc satura (biolog̣iskie, sociālie un garīgie);

- pēc funkcijas (tie, kas galvenokārt vada, un tie, kas veido darbības jēgu);

- pēc to nozīmes personības struktūrā [44]. 
Atkarībā no izpētes mērḳa motīvus iedala:

- psihologiskajos;

- krimināltiesiskajos;

- kriminologiskajos;

- kriminālistiskajos u. c.

Noziedzīgiem nodarījumiem tradicionāli tiek pieskaitīti arī tie pārkāpumi, kam ir augsta smaguma pakāpe, kas apdraud sabiedrību, indivīdu, kā arī "grauj vispārpien̦emtos priekšstatus par humānismu un taisnīgumu, kurus nekādā gadỉjumā nevar attaisnot apstākḷi un kuri tiek veikti aiz amorāliem motīviem" [27, 7]. Krimināltiesību doktrīnā noteikts, ka noziedzīga nodarījuma kaitīgums pieder noziedzīga nodarījuma objektīvajai pusei un jāuzskata par svarīgāko kriminālatbildības pamata īpašību [23, 61]. Profesors Uldis Krastinšs atzīmē, ka, vērtējot plašākā nozīmē noziedzīga nodarījuma radīto kaitējumu, redzams, ka katrs nodarījums izraisa kaitīgas sekas, kas izpaužas noteiktu, ar Krimināllikumu aizsargātu interešu apdraudējumā [19, 62]. Dr. iur. Andrejs Judins izsaka viedokli, ka ikviena rīcība, kas būtiski aizskar personu, sabiedrības un valsts intereses, jāvērtē kā bīstama [13, 28]. Noziedzīgam nodarījumam vienmēr ir sabiedriski bīstamas sekas jeb kaitējums. Objekts sastāv no sargājošām interesēm un aizsargājamām interesēm. Tieši aizsargājamās intereses cieš vienmēr [8, 190].

Individuālo noziedzīga nodarījuma mehānismu, domājams, var analizēt gan kriminologiiskajā, gan krimināltiesiskajā aspektā.

Šã pētījuma mērḳis ir parādīt saistîbu starp noziedzīga nodarījuma motīva kriminologiiskajām un krimināltiesiskajām - saturiskajām un konstruktīvajām - ìpatnībām. Šis pētījums ir aktuāls un būtisks, jo parāda noziedzīga nodarījuma mehānisma elementus un noziedzīga nodarījuma motīva nozīmi šajā mehānismā. Pētījuma gaitā tika izmantota aprakstošā, juridiski log̣iskā un dokumentālā pētišanas metode, kā arī tiesību interpretācijas metodes.

\section{Motīvs, motivācija - jēdzieniskais ietvars}

Termins "motīvs" (franču val. motif, latīnu val. mōtus - kustība, movēre - kustināt) svešvārdu vārdnīcā skaidrots šādi:

1) iekšèjs dzenulis, kas rosina, mudina uz kādu darbību vai ietekmē rīcību;

2) iemesls, ar kuru pamato rīcību vai nostāju [50, 559].

Profesors U. Krastinšš raksta, ka noziedzīga nodarïjuma motīvs ir cilvēka iekšējais pamudinājums, dziña, tieksme, kas virza vainīgā gribu uz noziedzīga nodarījuma izdarǐšanu $[19,62]$. Salīdzinājumam minēšu arī citus juridiskajā literatūrā dotos šā jēdziena formulējumus, lai parādìtu tajos iekḷautās motīva pazīmes.

Krimināltiesību jēdzienu skaidrojošā vārdnīcā noziedzīga nodarījuma motīvs tiek atspoguḷots kā dziņa, tieksme, personas iekšējais apzinātais pamudinājums izdarît noziedzīgu nodarījumu. Motīvs, līdzīgi nodarījuma mērḳim, tiek aprakstīts kā noziedzīga nodarījuma subjektīvās puses pazìme, kas raksturo tīšu noziedzīgu nodarījumu. 
Atsevišḳos krimināllikuma pantos motīvs tiek definēts kā kvalificējošs apstāklis [14, 31]. Dr. iur. Dainis Mežulis shematiski raksturojis, ka motīvs ir galvenais pamudinājums, kas personu virza uz nodarïjumu [39, 54].

Krievijas juridiskajā literatūrā sastopama šāda atziṇa: par noziedzīga nodarïjuma motīvu parasti tiek uzskatîts apzināts pamudinājums, kas virzījis personu, veicot noziedzīgu nodarïjumu. Tas ir darbības avots, iekšējās darbības virzītājspēks, ko nosaka personas vajadzības, intereses, kuras izraisa apnēmību paveikt noziedzīgu nodarījumu [55, 222].

Noziedzīga nodarījuma motīvs - tiešs, iekšējs pamudinājuma iemesls noziedzīga nodarījuma izdarīšanai (piemēram, greizsirdība, atriebība, savtīgums). Noziedzīga nodarỉjuma sastāvā motīvs ir subjektīvās puses pazīme. Krievijas Federācijas Kriminālkodeksā (KF KK) ir noteikts, ka atsevišḳos gadījumos motīvs ir obligāta vai kvalificējoša nodarījuma sastāva pazīme. Citos gadỉjumos tas var kalpot kā atbildību pastiprinošs vai atbildību mīkstinošs apstāklis $[5 ; 6]$.

Šajos formulējumos nav minētas lielas atškirīibas pēc būtības. Minētajās definīcijās uzmanība tiek vērsta uz tiešu, iekšēju un apzinātu pamudinājumu, kas virza uz noziedzīga nodarījuma izdarīšanu. Tas norāda uz krimināltiesību teorijā pastāvošo atziṇu, ka visi tǐšie noziedzīgie nodarījumi ir motivēti.

Par darbības vai bezdarbības motīviem var kalpot vajadzỉbas un intereses, aizraušanās un emocijas, nostādnes un ideāli. Vajadzību apmierināšana ir saistìta ar cilvēka kriminālās rīcības motivācijas formēšanos. Amerikāṇu psihologs Ēriks Froms izpētījis, ka cilvēkam ir piecas sociālās vajadzības, un, tikai apmierinot tās visas, cilvēks var pilnvērtīgi dzīvot. Katram cilvēkam ir nepieciešams:

1) gūt cilvēcisko saskarsmi;

2) būt kāda lielāka "mēs" elementam;

3) izjust pieķeršanos, simpātijas;

4) apzināties savu nozīmīgumu, vērtību un spējas, t. i., uzturēt savu pašapziṇu;

5) sevi apliecināt;

6) atrasties informācijas un vērtību orientāciju sistēmā.

Emocionālo saišu trūkums cilvēkam var kḷūt liktenīgs, uzsver psihologs E. Bērns $[45,14]$.

Visu savstarpēji saistīto motīvu sistēmu, kas nosaka personības uzvedību, sauc par motivāciju. No psiholog̣ijas viedokḷa motivācija tiek skaidrota kā vajadzības, intereses, pārliecỉba un citi uzvedỉbu veicinošie un vadošie elementi, kas ar attiecīgo darbību arī raksturo cilvēka personību. Motivācija ir noturīga attieksmju, priekšstatu, nostādṇu un uz tām balstīto personības ieviržu apkopojums, kas nosaka cilvēka uzvedību [46]. Motivācija vienmēr ir ierosmju komplekss: vajadzības, motīvi, ideāli, mērḳi, vērtību orientācijas $u$. tml. Visas šis ierosmes ir savstarpēji saistītas un veido sistēmu, kura arī nosaka cilvēka viengabalainu uzvedību, pieškir tai ievirzi un intensitāti. Motivācija veic vairākas funkcijas: rosina uzvedību, to vada un organizē, dod tai personisku jēgu un nozīmību $[52,200]$. 
Kriminologijāa ar motivāciju tiek saprasts rīcības motīvu kopums, kurā katrs no motīviem nosaka motivācijas elementu un pastāv kā apziṇas, tā zemapziṇas sfērā. Motīvi rodas un veidojas cilvēka emociju un jūtu iespaidā [43, 343]. Piekrītu profesores Ninel̦as Kuzṇecovas $($. Ф. Кузнецова) viedoklim, ka personas motivāciju visbiežāk jāskata caur motīva kompleksa prizmu (retāk - vienu motīvu). Motīvs var būt stimuls, kura priekšplānā aktualizējas konkrētas darbības (bezdarbības) mērḳis un kurš ir personas uzvedības iemesls $[25,95]$.

Tātad starp motīvu un mērḳi pastāv saistība (sk. 1. att.). Motīvs un mērḳis ietekmē nodoma rašanos, tā virzību uz mērķi un nodoma īstenošanos. Mērḳis (nolūks) ir iecerētais rezultāts, ko persona, izdarot noziedzīgu nodarījumu, vēlas sasniegt $[19,108]$.

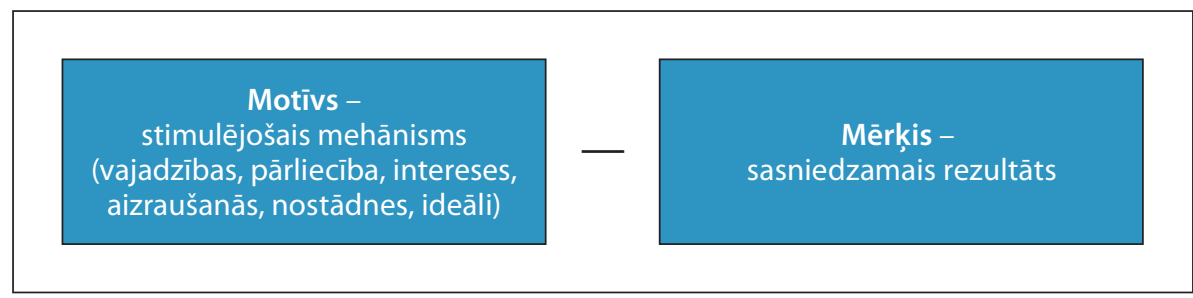

1. attēls. Motīva un mērḳa savstarpējā saistỉba

Mērḳa nozīme izpaužas tajā apstāklī, ka tas nosaka vainīgā gribu, balsta to uz noziedzīgā nodarījuma izdarīšanu [19].

Piemēram, zādzības motīvs vienmēr ir mantkārība, bet mērḳis - iegūt materiālu labumu, tas ir, iedzīvoties uz citas personas rēḳina [22, 6-19]. Dažos noziedzīgos nodarījumos var savìties pēc savas nozīmes un lomas atškirīgi motīvi, piemēram, slepkavības motīvi vienlaikus var būt atriebība un mantkārība, greizsirdỉba un atriebība [19].

Tiesu praksē krimināllietās, kas atbilst Latvijas Krimināllikuma 317. panta 2. daḷai, 318. panta 2. daḷai un 319. panta 2. daḷai, teikts, ka krimināltiesībās ar mantkārīgu nolūku saprot personas vēlmi noziedzīga nodarỉjuma rezultātā iegūt jebkāda veida nepienākošos materiālos vai cita rakstura labumus sev vai citām personām. Turklāt ar labuma gūšanu jāsaprot ne tikai tā iegūšana, bet arī sevis vai citas personas atbrīvošana no nevēlamiem izdevumiem. Tiesu prakses materiālu analīze parādīja, ka apsūdzētās valsts amatpersonas, galvenokārt izmantojot savu dienesta stāvokli, vēlējušās nelikumīgā veidā iegūt naudas līdzekḷus, iegūt savā īpašumā dzīvokli, datoru un kādus citus labumus [31].

Krimināllikuma zinātniski praktiskajā komentārā sniegts skaidrojums, ko atzīt par mantkārīgos nolūkos izdarītu slepkavību (atkarībā no tā, kādu rezultātu vainīgais vēlējies sasniegt):

1) slepkavība, kuras mērḳis ir nelikumīgi iegūt materiālos labumus (mantu, naudu, tiesības uz mantu, tiesības uz apdzīvojamo platību, iespēju izmantot cietušā apdzīvojamo platîbu); 
2) slepkavība, kuras mērḳis bijis izvairīties no materiāliem izdevumiem (parāda atdošanas, patapinātas mantas atdošanas, uzturēšanas, pakalpojuma maksas vai kādu citu mantisku saistību izpildīšanas u. tml.) [20].

Speciālajā literatūrā nav vienotas nostājas par motīvu klasificēšanu. Noziedzīga nodarījuma motīvu daudzveidīga klasifikācija atrodama Krievijas juridiskajā literatūrā. Profesors Viktors Luṇejevs (В. В. Аунеев) iesaka noziedzīgās rīcības motīvus iedalīt politiskajos, mantkārības, vardarbīgi egoistiskajos un anarhiski individuālajos [38, 382].

Noziedzīga nodarījuma motīvus var klasificēt pēc nodarījuma smaguma:

1) antisociālie (grieķu val. anti... - pret, priedēklis, ar ko apzīmē pretstatu, nesaderību vai naidīgumu) motīvi - politiskie, vardarbīgie, mantkārības, mantkārīgi agresīvie u. c.;

2) asociālie (pretsabiedriskie, t. i., tādi, kas vērsti pret sabiedrības tiesībām un interesēm) motīvi - to kaitīguma pakāpe ir mazāka nekā antisociālajiem, tie ir mazāk sabiedriski bīstami - egoistiskie, individuāli anarhiskie (autoritātes, kārtības un disciplīnas neatzī̌sanas) u. c.;

3) pseidosociālie motīvi - aprobežojas ar atsevišķu sociālo grupu interesēm, kuras ir pretrunā krimināltiesiskajam regulējumam, indivīda un sabiedrības interesēm, piemēram, fiktīva kooperācija, kuras pamats ir ekonomisko noziegumu izdarǐšana;

4) protosociālie (prot(o)... grieḳu val. prötos - pirmais, salikten,a pirmā sastāvdaḷa, kas nozīmē - sākotnējs, pirmējs, primārs vai augstākais, galvenais) motīvi sociāli labvēlīgu uzvedības motīvu pāraugšana sociāli nelabvēlīgos motìvos, piemēram, nepieciešamās aizstāvēšanās robežas pārkāpšana.

Teorētiskās un praktiskās atziṇas rāda, ka cilvēka rīcību var izraisìt viens vai vairāki motīvi, kas mēdz būt gan apzināti, gan neapzināti. Ja apsūdzētajam bijuši vairāki motīvi, tad kāds vienmēr ir dominējošais un nosaka noziedzīgā nodarījuma kvalifikāciju [32]. Tāpēc motīvus var iedalīt arī šādi:

1) galvenais jeb primārais;

2) papildu jeb sekundārais.

Docents Beniamins Ogaṇesjans (Б. $\Lambda$. Оганесян) uzskata, ka krimināltiesībās ir nozīme divu veidu motīviem un tie ir:

1) zemiskais (nelietīgais);

2) bez (nav) nelietīga rakstura.

Šis autors norādījis, ka KF Kriminālkodeksa dispozịcijās galvenokārt tiek norādīti zemiskie motīvi: mantkārība, huligānisms, personīgā ieinteresētība (atriebība, skaudība, karjerisms) u. c., taču ir daži noziedzīgi nodarījumi, kuriem nav nelietīga motīva, piemēram, nepieciešamās aizstāvēšanās robežu pārkāpšana - centieni pārtraukt noziedzīgo nodarījumu [41, 287-289].

Domājams, šādam iedalījumam var piekrist, jo, piemēram, runājot par eitanāzijas motīviem, var norādīt uz žēlsirdību. Eitanāzijas motīvs ir žēlsirdība, jo tās mērḳis ir personas ciešanu novēršana. "Aktīvā eitanāzija" nozīmē tîšu, ātru un nesāpīgu 
nedziedināmi slimas personas nonāvēšanu pēc tās lūguma ar mērḳi atbrīvot vinu no mokošām fiziskām un psihiskām ciešanām (izdarīšanas motīvs ir žēlsirdība) [11, 34]. Atkarībā no motīva tiesiskā, morālā un politiskā izvērtējuma Plehans Dageḷs (П. С. Аагель) noziedzīga nodarïjuma motīvus iedala:

1) zemiskajos jeb sabiedriski bīstamajos (politiskie, reliǵiskie un personiskie motīvi - savtīgums, skaudỉba, atriebība u. c.);

2) sabiedriski neitrālajos (aizraušanās, aizvainojums, kauns u. c.);

3) sabiedriski pozitīvajos (nepareizi izprastas valsts, zinātniskās intereses, radnieciskās saites, personas, īpašuma vai sabiedrisko interešu aizsardzība u. tml.) $[48,326]$.

Motīvu iedalījumi ir vairāki. Tie tiek iedalīti arī šādās divās grupās:

1) motīvi, kas saistīti ar ideju, pasaules uzskata galveno principu, sīkāk tos iedalot apakšgrupās: vispārēji sociālajos (morāli politiskajos, ētiskajos un reliǵiskajos) un personiska rakstura (zemiskajos - mantkārības, egoistiskajos, saistītos ar noskanojumu, afektiem u. tml.);

2) motīvi, kas saistāmi ar priekšmetisko ieinteresētību, proti, interesi izraisa priekšmets.

Sastopama arī motīvu klasifikācija, kuras pamatā ir sociāli psiholog̣iskais un tikumiski ètiskais princips [54, 184-191].

Var secināt, ka motīvs ir tas, kas atspoguḷojas cilvēka apziņā, pamudinot vinuu uz darbošanos, lai apmierinātu savas vajadzības, aizraušanās, vēlēšanās un intereses. Indivīda vadošie rīcības motīvi nosaka viṇa dzīves stilu.

Apkopojot šeit minēto, noziedzīga motīva funkcijas var iedalìt šādi:

- pamudināšanas un virzišanas funkcijas;

- rīcíbas jēgu un nozīmi veidojošās funkcijas.

Rezumējot jānorāda, ka noziedzīga nodarījuma motīvs ir tas aktīvais spēks un avots, kas personas kaitīgo rīcību virza uz noteikta noziedzīga mērḳa sasniegšanu. Motivācija ir stimulu (motīvu) sistēma, kas pamudina cilvēku uz rīcību vai bezdarbību.

Krievijas tiesību zinātniece Jeḷena Lukaševa (Е. А. Аукашева) pauž atbalstāmu viedokli, ka noziedzīgs nodarỉjums ir motīvu objektivizēšanas un izteiksmes forma; savukārt motīvs ḷauj izprast tiesiskās vai prettiesiskās uzvedības patieso raksturu [37, 2-6, 8].

Noziedzīgs nodarījums tiek paveikts pēc tam, kad pamudinājums (dziṇa, vajadzība) apziṇā ir ticis apsvērts kā darbība un paredzētas tās sekas. Pēc lēmuma pieṇemšanas cilvēks pievēršas fiziskai darbïbai. Motīvs un mērḳis izveidojas pirms noziedzīga nodarījuma uzsākšanas. Tikko apgalvoto ilustrēšu ar piemēru - Latgales apgabaltiesas spriedumu: persona B. kopā ar personu A. atradās A. vecmammas mājā, kur lietoja alkoholiskos dzērienus. Vakara gaitā B. un A. vienojās veikt laupīšanu - iekḷūt divu tuvākajā apkārtnē dzīvojošo sieviešu mājās un nolaupît viņām piederošo naudu un citas mantas, apzinoties, ka abas sievietes ir vientuḷas un vienas pašas nespēs pretoties, kā arī neziños par noziegumu. Realizējot savu nodomu, B. un A. no dzīvesvietas līdzi paṇēma cimdus un virtuves nazi, bet B. paṇēma arī melnu cepuri, kurai izgrieza caurumus acìm, 
savukārt A. uzvilka melnu virsjaku ar kapuci, kuru uzlika galvā un cieši nosēja aukliņas, lai nevarētu saredzēt seju [30].

Noziedzīga nodarījuma motīvam un mērḳim ir krimināltiesiska un kriminologiska nozīme. Domāju, ka tie sniedz iespēju noskaidrot patiesību lietā. Analizējot noziedzīgu nodarījumu, profesors U. Krastiņš norāda, ka "motīvs un mērḳis ir patstāvīgas noziedzīga nodarījuma subjektīvās puses pazīmes, kas - tāpat kā vaina - pierādāmi krimināllietā, ja tie saskaṇā ar Krimināllikumu ietverti noziedzīga nodarījuma sastāva pazìmju skaitā" $[19,108]$.

\section{Noziedzīgas rīcības motīva kriminologiskais aspekts}

Nenoliedzami, kriminolog̣ijas zinātnē nozīmīgi ir izpētît, kas cilvēkus rosina, mudina uz noziedzīgu rīcību. Manuprāt, motīvs kriminologijā ir svarīgs noziedznieka uzvedības izpētes elements, jo tas atklāj iemeslu, kas pamudina cilvēku veikt noteiktu darbību. Uzskatu, ka kriminolog̣iskā pieeja salīdzinājumā ar krimināltiesisko pieeju ir plašāka, jo l̦auj izzināt personības formēšanās un noziedzīga nodarījuma veidošanās un izdarīšanas mehānismu, kā arī tai ir būtiska nozīme noziegumu novēršanas un apkarošanas darbā.

Kriminologiijas mācību literatūrā tiek skaidrots, ka jebkura indivīda rīcības pamatcēlonis ir viṇa vajadzības un intereses, kas veidojušās socializācijas procesā. Vajadzības ir savdabīgs cilvēka darbības dzinulis, un tās atspoguḷo materiālo vērtību (ēdiena, apgeērba, mitekḷa), sazināšanās, izziṇas, seksuālo tieksmju apmierināšanas nepieciešamību [24, 249]. Cilvēka vajadzības var būt dažādas: materiālas, intelektuālas, morālas, estētiskas, seksuālas, kā arī vajadzība kontrolēt, dominēt un būt vardarbīgam u. tml.

Kriminologiijas klasiskās skolas pārstāvji noziedzīgu nodarījumu aplūko kā pavisam racionālu kategoriju, nepieškirot nozīmi noziedznieka garīgajam stāvoklim vai sociālās vides ietekmei. Noziedzīgu nodarījumu šì virziena pārstāvji traktē kā personas izvēli, pastāvot tikai diviem nosacijumiem:

1) rīkojoties saskanāā ar tiesisko regulējumu;

2) riskējot, pārkāpjot likumu, un ar šādu uzvedību vēloties sasniegt kādu personisku labumu vai peḷnu.

Vairākumā gadījumu noziedzīgs nodarījums netiek ìstenots spontāni; motīvs un lēmums to realizēt tiek apsvērts noziedznieka apziṇā pirms noziedzīgas rīcības ìstenošanas. Konkrētam noziedzīgam nodarījumam ir iepriekšējs sava veida individuālas psihiskās darbības ievadījums.

Par šiem jautājumiem ir vairākas kriminolog̣iskās teorijas:

- Iespēju teorija (Crime Opportunity Theory), kuras pārstāvji apgalvo, ka likumpārkāpējs veic izvēli, izraugoties mērḳi, kas sniedz augstu atdevi ar minimālu piepūli un risku. Piemērots mērḳis (persona, objekts, ìpašums) tiek noteikts un vērtēts pēc šādiem kritērijiem: vērtība, inerce (kustības daudzums), redzamība, pieklıve (VIVA - Value, Inertia, Visibility, Access). 
- Racionālās izvēles teorija (Rational Choice Theory), kuras atbalstītāji pauž uzskatu, ka noziedznieks vienmēr tiecas gūt labumu no noziedzīgiem nodarījumiem. Šis labums var nebūt materiāls, piemēram, zādzības gadījumā, jo ir daudzi citi ieguvumi no noziedzīgiem nodarījumiem, tostarp seksuāls apmierinājums, apreibināšanās, sajūsma, atriebība, biedru cien̦a [15, 97]. Tātad tiek pien,emts, ka noziedznieki, veicot noziedzīgus nodarỉjumus, meklē ieguvumus, kas viniem ir pietiekami lietderīgi un pamatoti.

- Ikdienas aktivitātes teorija (Routine Activity Theory), kuras pārstāvji apgalvo, ka, piemēram, laupīšana notiek, kad iespējamais noziedznieks un piemērotais mērḳis satiekas laikā un vietā un mērḳis netiek pietiekami aizsargāts. Šādi tiek apstiprināta iespējamā noziedznieka faktiskā pastāvēšana, jo cilvēka alkatība un savtība ir pietiekams skaidrojums noziedzīgas rīcības motivācijai [15, 97].

- Sociālās kontroles teorijā (Social Control Theory) tiek piel̦auts, ka cilvēki var saskatīt noziedzības priekšrocības un spēj izdomāt un realizēt dažādas noziedzīgas darbïbas nevilcinoties jeb momentā - bez īpaša stimula vai iepriekšējas apmācības. Tiek piel̦auts, ka primārais ir potenciālais ieguvums no noziedzīga nodarījuma.

Analizējot noziedzīgas uzvedības mehānismu, jāṇem vērā, ka vide, kurā atrodas indivīds, un personas individuālās īpašības nosaka ietekmi uz visiem kriminālās uzvedības veidošanās posmiem:

- motīva formēšanos;

- lēmuma pien̦emšanu par noziedzīga nodarījuma izdarǐšanu.

Apstākḷu kompleksu, kas izraisa konkrētu noziedzīgu nodarījumu, Valdis Birkavs diferencē šādās grupās:

- personības tikumiskās veidošanās nelabvēlīgi apstākḷi;

- noziedzīga nodarījuma izdarīšanas iemesls, ko rada konkrēta dzìves situācija;

- apstākḷi, kas atvieglo noziedzīga nodarïjuma izdarīšanu $[49,63]$.

Motivācija ietver noziedzīgas rīcības motīva un mērḳa rašanās un veidošanās procesu. Uzvedības motīvs - iekšējs pamudinājums uz rīcību (darbību), vēlēšanās, kas nosaka vajadzības, intereses un jūtas, kuras radušās un saasinājušās apkārtējās vides ietekmes un konkrētās situācijas dēḷ.

Pēc motīva izveidojas mērḳis kā noteiktas darbības paredzamais un vēlamais rezultāts. Atkarībā no satura noziedzīga nodarījuma mērḳi var būt daudzveidīgi:

- iedzīvošanās;

- savtīgums (savtīga nolūka);

- kaitējuma nodarī̌̌ana personai vai sabiedrībai;

- egoistisks;

- mantas realizācija u. tml.

Motivācijas veidošanos ietekmē gan vides, gan personīgie apstākḷi. Jāpiemin, ka noziedzīgs nodarījums ir indivīda vienota gribas darbỉba, kam raksturīgi sarežgìti psihologiskie procesi, kurus ietekmē ne tikai ārējie apstākḷi, bet arī dažādi personas individuālie apstākḷi. 
Manuprāt, personas rīcības motivētājus var iedalīt individuālos jeb iekšējos un ārējos. Savukārt motīvus, kas ietilpst noziedznieka motivācijā, var iedalīt šādās pamatgrupās:

- sadzīviskie;

- sociāli nozīmīgie;

- saskarsmes un mijiedarbibas;

- personas attīstības un socializācijas (sociālās prasmes, kontakti, vērtības).

Iepriekš minētā rezumējums atspoguḷojas Dr. oec. profesores Silvijas Kristapsones teiktajā, ka noziedzīgas uzvedības cēloṇi ir visu pagātnes, tagadnes un iespējamo nākotnes sociālo iedarbību kopums mijiedarbībā ar noziedzīgu nodarījumu izdarījušas personības īpatnībām. Nereti nozieguma izdarǐšanas brīdī daudzi cēloṇi ir pārstājuši objektīvi eksistēt, tomēr atstājuši savas pēdas, tādējādi esot personas uzskatu, paradumu, vērtību utt. pamatā. Tādējādi cēloṇus un apstākḷus, kas darbojas nozieguma izdarīšanas brī̄ī, subjekts apzināti vai neapzināti atlasa kā personīgi svarīgu informāciju, kas tiek "lauzta caur psihes prizmu" un realizējas caur konkrētiem motīviem, mērḳiem un vēlmēm (sk. 2. att.) [27, 7].

Motīvs ir personas noziedzīgas rīcības pamats, iekšējs virzītājspēks un aktivitātes rosinātājs, ko nosaka vajadzību un interešu apmierināšana un kas rodas un izveido personas lēmumu izdarīt noziedzīgu nodarījumu. Savukārt vajadzības ir viss, kas nepieciešams normālai cilvēka dzìvei, bet konkrētajā brīdī personai tā trūkst. Uzvedības un rīcības motivāciju būtiski ietekmē personības galvenās ievirzes, personīgās trauksmes līmenis un šis līmenis dažādās situācijās, iekšējie konflikti un neapmierinātās vajadzības. Turklāt jānorāda, ka rīcību virza un cilvēka aktivitāti izraisa iekšējie dzinuḷi, vērtīborientācija, pārliecỉba, nostāja, intereses, vēlmes, dziṇas u. tml.

Nedaudz vairāk pievēršoties dzimumnoziedznieku motivācijai, jāteic, ka seksuāli prettiesiska rīcība ir personas nespēja sasniegt savus mērḳus sociāli pieṇemamā veidā, tādēḷ šis cilvēks izvēlas citus veidus.

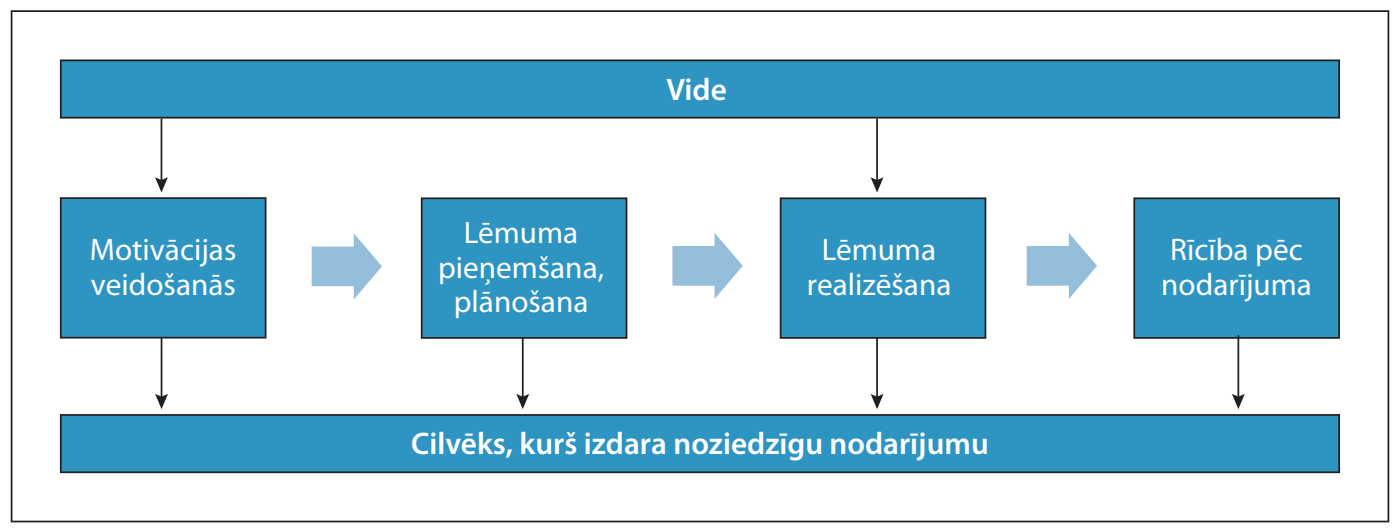

2. attēls. Noziedzīgas uzvedības mehānisms [26] 
Speciālajā literatūrā dažādi krimināli agresīvās uzvedības motīvi tiek iedalīti šādi:

1) impulsīvie, kas atbilstīgi situācijai subjektam rodas sarežğìtos apstākḷos, to pamatā ir stipras emocijas;

2) instrumentālie - noteiktu mērḳu sasniegšanai, cietušā pretošanās pārvarēšanai, upura piespiešanai veikt kādas darbības;

3) naidīgie - agresijai realizējoties kā pašvērtējumam, bieži vien agresīvā uzvedība tiek veikta, lai pazemotu upuri, panirirgātos par to;

4) grupas solidaritātes - grupas atzinības iegūšanai [4, 178].

Anomijas pētnieks Roberts Mertons (R. K. Merton) uzskata, ka tās cēlonis var būt pretrunas starp sabiedrības mērḳiem un to sasniegšanai izvēlētajiem līdzeklịiem. Pētnieks apgalvo, ka anomija nav dezorganizētas sabiedrības stāvoklis, bet gan personības ar izkropḷotu morāli stāvoklis.

Amerikāṇu kriminologs Roberts Agnevs (R. Agnew), izveidojot Vispārējo sasprindzinājuma teoriju (General Strain Theory), uzskata, ka dusmām ir nozīmīga ietekme uz noziedzīgu rīcību un devianci (sasprindzinājums $\rightarrow$ dusmas $\rightarrow$ krimināla uzvediba) [3, 398].

Persona, kura izdara seksuāla rakstura noziedzīgus nodarījumus, jūt vajadzību kontrolēt un dominēt pār upuri vai to l̦aunprātīgi izmantot un pazemot. Krievijas pētnieki uzskata, ka dzimumnoziedznieka galvenais motīvs ir dzimumtieksmes apmierināšana rupjā, dzīvnieciskā veidā. Dažkārt vainīgā seksuālie dzinuḷi kombinējas ar huligāniskām tieksmēm, vēlmi atdarināt vecākos biedrus, pazemot vai apkaunot upuri, paṇirgāties par cietušo, atriebties, pašapliecināties u. tml. [47, 220-225].

Parasti vardarbīgā noziedznieka uzvedības dominējošais motīvs ir vēlme apmierināt vajadzību pēc vardarbības, agresijas vai cietsirdỉbas [4, 178]. Amerikāṇu speciālisti atzīst, ka izvarotājam dzimumsakari neizpaužas seksuālā vajadzībā, tiem raksturīgas šādas pazīmes: vara, spēks un dusmas [9, 30]. Vairāki autori (R. Šneiders, K. Neidelsons, M. Notmens, Dž. Perlmutters) uzsver, ka izvarošanas būtība galvenokārt ir vardarbībā pret personu, tās dzīvības apdraudējumā, nevis seksuālajā dabā [7, 47]. Izvarotājus vada šādi iekšējie dzinuḷi: vientulība, seksuālā interese un dusmas. Pētījumā atklāts, ka visbiežāk izvarotājs pārdzīvo dusmas: 88\% gadījumu - dusmas vispār, 77\% - dusmas pret sievieti. Piekrītot, ka izvarošanu veicinošais faktors ir dusmas vai spēks (vara), pētnieks Nikolas Grots (N. A. Groth) izšḳir šādus izvarotāja motivācijas veidus:

1) uzbudinājuma dusmas (excitation anger);

2) atriebibas dusmas (retaliation anger);

3) varas apliecinājums (power reassurance);

4) varas dominante (power dominant);

5) oportūnistiska attieksme (oportunistic) [12, 161].

Savukārt noziedzīgo nodarījumu motīvu raksturojumā kā specifiskus var nodalīt amatpersonu noziedzīgās rīcības motīvus. Atbilstīgi Kārla Fridriha (C. J. Friedrich) skaidrojumam korupcija ir uzvedība, kurai piemīt novirze no politiskajā sfērā valdošām normām un kuru izraisa motivācija iegūt personisko labumu uz sabiedrības rēḳina [10]. 
Apspriežot amatpersonu motivāciju veikt koruptīvās darbības publiskajos iepirkumos, eksperti pārsvarā ir vērsuši uzmanību uz amatpersonu mantkārību, vēlmi iegūt papildu ienākumus, naudu, materiālos vai personīgos labumus, politisko atkarību, kā arī varas saglabāšanu, partiju finansēšanu, centienus demonstrēt paklausību priekšniekam, apmierināt citas kaislibas.

Jautājumā, kāds ir komersantu galvenais motīvs veikt koruptīvās darbības publiskajos iepirkumos, tiek norādīta šāda motivācija:

1) saņemt lielāku peḷnu;

2) iegūt privilegétu stāvokli un attīstīt savu biznesu;

3) iegūt pasūtỉjumu - peḷnai vai izdzīvošanai;

4) dabūt darbu un izdzīvot krīzes laikos;

5) izvairīties no bankrota $[28,21]$.

Ukraiṇu speciāliste Svetlana Šalgunova (С. А. Шалгунова) piedāvā kukuḷnēmēju mantkārības motīvus klasificēt sešās apakšgrupās:

1) naudas, materiālo vērtību krāšanas kāre un tiekšanās sasniegt materiālu komfortu, lai nedzīvotu sliktāk "kā citi";

2) alkohola atkarība (to, manuprāt, jāpaplašina, norādot uz adiktīvu uzvedību);

3) viegla un bezmaksas eksistence;

4) dienesta materiālo vajadzību apmierināšana - cenšanās izpatikt priekšniecībai, uzturēt dienesta vajadzībām formālas un neformālas attiecības;

5) apmierināt vitālas ǵimeniski sadzìviskas vajadzības (zāles, apgeērbs, mēbeles);

6) realizēt un izjust risku, t. i., rezultāts nav svarīgs, bet būtiskas ir "asas izjūtas" (paaugstināta riska pakāpe).

Pamatojoties uz profesora V. Luṇejeva koncepciju, tiek piedāvāts analizēt šādus tiesībsargājošo iestāžu darbinieku noziedzīgos motīvus:

1) mantkārības motīvi - tā mērḳis ir uzlabot materiālo stāvokli;

2) vardarbïbas motīvi (greizsirdība, dusmas, egocentrisms, atriebỉba, huligānisms);

3) "idejiskie" motīvi (идейнье мотивы) - vēlme atjaunot taisnīgumu, ticība likuma nemaldīgumam, nekonsekventa attieksme pret likumpārkāpumu, principiāla attieksme;

4) konformistiskie motīvi - vēlme būt kā visiem, nevēlēšanās izrādīt iniciatīvu, pasliktināt savstarpējās attiecības, centieni atdarināt kolēgus, uzlūkot vinus par paraugu u. tml.;

5) vieglprātīgie un bezatbildīgie motīvi - izvairīšanās no jebkādu sarežǵìjumu risināšanas, savu kḷūdu neatzīšana, dzīvošana šai dienai, nedomājot par turpmāko, u. tml.

Noziedzības izpētes diskursā būtiskas ir noziedzības apkarošanas un novēršanas jomas. Sabiedrības evolūcijas gaitā cinna ar noziedzību ir attīstījusies divos virzienos tās novēršanā un apkarošanā. Krimināltiesību pētniece Ilona Kronberga raksta, ka noziedzības novēršana nozīmē iejaukšanos notikumos vai cilvēka uzvedībā, lai novērstu likumpārkāpumus [29]. 
Korupcijas novēršanas un apkarošanas pamatnostādnēs 2015.-2020. gadam apzināts, ka viens no valsts un pašvaldību sektoru tieši skarošiem apakšmērkiem ir nodrošināt publiskās pārvaldes cilvēkresursu vadības politiku, kas nepieḷauj koruptīvas rīcības motivāciju. Šā apakšmērḳa sasniegšanai plānotajos rīcības virzienos ietverta personu loka, uz kuru attiecināmi preventīvie pretkorupcijas pasākumi, pārskatî̌ana un publiskās pārvaldes cilvēkresursu vadība, lai veicinātu ētiskumu un mazinātu korupcijas un interešu konflikta riskus [16].

Darbs ar noziedzniekiem atspoguḷots pētījumā "Sabiedriskā darba nozīme sociālās atstumtības mazināšanā". Tajā apzināts, ka jaunieša motivāciju mainīt savu ierasto sociālās uzvedības modeli ir iespējams panākt, kombinējot sodu ar interesantiem piedāvājumiem (iesaistī̌̌anos ārpusskolas aktivitātēs) - gan ar pieaugušo, uzvedības korekcijā iesaistīto profesionālu, sirsnīgu un ieinteresētu attieksmi, gan ar interešu korekciju (piemēram, speciāliem uzvedības korekcijas pasākumiem, atkarību ārstēšanu, profesionālo orientācija). Turklāt darbā ar dzimumnoziedzniekiem Lielbritānijas speciālisti pievērš uzmanību faktoriem, kam ir nozīme dzimumnoziegumu izdarīšanā, cilvēka domām un uzskatiem, proti, priekšstatiem par seksualitātes lomu dzīvē, par vīriešu, sieviešu un bērnu attiecībām, indivīda spēju kontrolēt savas emocijas un uzvedību, prasmi veidot attiecības. Nozīme ir arī alkoholisko dzērienu un narkotiku lietošanai, kas veicina noziedzīgu uzvedību. Protams, nopietnas problēmas šajā sfērā ir ne tikai dzimumnoziedzniekiem, bet arī citām personām, kuras izdara visdažādākos nodarījumus. Attiecībā uz dzimumnoziedzniekiem l̦oti svarīgi ir saprast, kādu funkciju šo cilvēku dzīvē pildījis noziegums, kādas cilvēka vajadzības tas apmierinājis. Terapija ("Temzas ielejas programmas") palīdz atrast veidus, kā šìs vajadzības apmierināt sociāli un ètiski pieṇemamā veidā [1].

\section{Krimināltiesiskais konteksts}

Atbilstīgi Kriminālprocesa likuma 124. panta noteikumiem kriminālprocesā jāpierāda noziedzīgā nodarījuma sastāva esamỉba vai neesamība.

Noziedzīga nodarījuma sastāvu, kā zināms, veido četri obligātie elementi:

1) objekts;

2) subjekts;

3) objektīvā puse;

4) subjektīvā puse.

Jāpiemin arī, ka Latvijas krimināltiesībās noziedzīga nodarījuma sastāva pazīmes iedala pamatpazìmēs un papildpazìmēs.

Noziedzīga nodarījuma subjektīvā puse ir vainīgās personas (nodarījuma subjekta) psihiskā darbība, kas tieši saistīta ar izdarīto (nodarījuma objektu un objektīvo pusi), un tā apvieno vienotā veselā personas psihiskās darbības intelektuālos un gribas procesus [19]. Noziedzīga nodarījuma subjektīvās puses pamatpazìme ir vaina. Krimināllikumā vaina tiek saistīta ar nodoma (tiešs nodoms, netiešs nodoms) vai 
neuzmanības formu (noziedzīga pašpal̦āvība, noziedzīga nevērība). Juridiskajā literatūrā tiek apskatīta arī dubultā forma, kuras pamatā ir personas dažādā psihiskā attieksme pret atseviškām noziedzīga nodarījuma objektīvās puses pazīmēm.

Noziedzīga nodarījuma pamatpazīmju juridiskā nozīme izpaužas tādējādi, ka tām obligāti jābūt ikviena konkrēta noziedzīga nodarījuma sastāvā. Par obligātu noziedzīga nodarijjuma subjektīvās puses pazìmi motīvs kḷust tad, ja tā norādìts Krimināllikuma Sevišķās daḷas panta dispozīcijā $[18,184]$. Atškirīibā no nolūka (mērḳa) nodarījuma motīvs kā nodarījuma obligātā pazīme tiek lietots diezgan reti.

Profesors U. Krastiņš norāda, ka Krimināllikumā diezgan bieži noziedzīga nodarījuma sastāvi tiek konstruēti tādā veidā, ka panta dispozīcijā nav īpaši norādìts uz motīvu vai mērḳi kā obligātu nodarījuma sastāva subjektīvās puses pazīmi, taču, lai konstatētu attiecīgā noziedzīgā nodarījuma sastāvu, motīvs un mērḳis ir obligāti jāpierāda. Gadījumos, ja notikusi slepkavība, būtiska nozīme ir precīzai vainīgā motīva noskaidrošanai, jo tīša nonāvēšana saskaṇā ar Krimināllikuma 116. pantu kvalificējama tad, ja tã izdarīta personisku attiecību dēl, greizsirdības, atriebības, naida, strīda un citos līdzìgos gadījumos [42, 20].

Papildpazīmes likumdevējs ir ietvēris atsevišḳu noziedzīgo nodarījumu sastāvos kopā ar nodarījuma sastāva pamatpazīmēm [19]. Papildpazīmes ir obligātas, ja tās ir ietvertas Krimināllikuma Sevišḳās daḷas normā, piemēram, nodarījuma izdarǐšanas laiks, vieta, veids, noziedzīga nodarījuma priekšmets, cietušais, noziedzīga nodarījuma izdarīšanas motīvs un mērḳis. Salīdzinošam pārskatam piedāvāju Dr. iur. Agneses Beḷskas atziņas, kas gūtas, analizējot ASV krimināltiesībās minētos elementus un salīdzinot tos ar elementu un pazīmju izpratni Latvijas krimināltiesībās. Viṇa secina, ka, pirmkārt, atsevišķas Latvijā tā dēvētās papildpazīmes ASV krimināltiesībās tiek pētītas kontekstā ar kāda no pamatelementu izpausmes veidiem, piemēram, motīvs tiek uzskatìts par nolūka vai mērḳtiecības pamatu. Otrkārt, atsevišķas papildpazīmes, piemēram, blakusapstākḷi, tiek izvirzìtas par noziedzīga pārkāpuma patstāvīgu elementu [2].

Noziedzīga nodarījuma subjektīvā puse atspoguḷo saikni starp personas apziņu un gribu, un viņas izdarīto nodarījumu. Dominējošais ir uzskats, ka psiholoğiskais noziedzīgā nodarījuma subjektīvās puses saturs tiek atklāts ar šādu juridisku pazìmju palīdzību: vainu, motīvu un mērḳi (nolūku), kas raksturo personas dažādās psihiskās aktivitātes formas. Vainas pakāpe tiek noteikta, par pamatu n,emot arī nodarījuma objektīvos apstākḷus (ciktāl tos aptver subjekta psihiskā attieksme), noziedzīgā nodarījuma raksturu, subjektīvās attieksmes īpatnības pret darbību vai bezdarbību, noziedzīgā nodarījuma motīvu un mērḳi, cēloṇus un apstākḷus, kas ietekmēja nodoma rašanos vai izraisija neuzmanību, u. tml.

Motīva un mērḳa atškiršana no nodoma kā vainas formas tiek izdarīta teorētiski, un tie kā pazīmes noder, lai pareizi izprastu vainīgā psihiskās darbības saturu un virzību un varētu noteikt personas vainu konkrētajā gadījumā $[18,128]$. Noziedzīga nodarījuma motīvs tiek n,emts vērā nodarījuma kvalifikācijas procesā soda veida un smaguma noteikšanai. Motīvs ir atbildību pastiprinošs vai mīkstinošs apstāklis, 
piemēram, naida motivācija kā atbildību pastiprinošs apstāklis, ja noziedzīgs nodarījums izdarīts rasistisku, nacionālu, etnisku vai reliǵisku motīvu dēḷ (Krimināllikuma 48. panta 1. dalıas 14. punkts).

Asociētais profesors Mārtiņš Mits raksta, ka naida noziegumu motīvs tiek definēts, izmantojot vienu no diviem modeliem - naidīguma vai diskriminācijas modeli. Naidīguma model̦a gadījumā tiek prasīts konstatēt pret personu vērstu naida izpausmi vai nicinošu attieksmi. Savukārt diskriminācijas model̦a izmantotājam jānoskaidro, ka vēršanās pret personu ir notikusi kādas šo personu vai personu grupu raksturojošas pazìmes dēḷ [40, 28-29].

Motīvs un mērkis var būt ietverts noziedzīga nodarījuma sastāvā kā obligātā pazīme, un tad tie ietekmē nodarījuma kvalifikāciju, piemēram, slepkavība mantkārīgā nolūkā (KL 117. panta 9. punkts). Ja motīvs un mērḳis nav ietverti noziedzīga nodarījuma sastāva pazīmju skaitā, tad tie neietekmē nodarỉjuma kvalifikāciju, kaut arī neviens ar tiešu nodomu izdarìts nodarïjums netiek izdarìts bez motīva un mērḳa [20].

Kvalificējot noziedzīgo nodarījumu atbilstīgi likuma prasībām, jākonstatē visas nepieciešamās un obligātās attiecīgā noziedzīgā nodarījuma sastāva pazīmes, to skaitā subjektīvā puse, kas ietver nodomu. Krimināllikuma 175. pantā paredzētais noziedzīgais nodarījums - zādzība - var tikt izdarīts tikai ar tiešu nodomu, bet šo nodomu raksturo mantkārīgs motīvs, kaut gan tas nav tieši norādīts minētajā likuma normā.

Piemērs no tiesas sprieduma: no lietas materiāliem, konkrēti, no pirmās instances tiesas sēdes protokola, redzams, ka tiesas debatēs prokurore I. K. izteica viedokli, ka apsūdzētā U. G. noziedzīgā nodarījuma motīvs ir iebiedēšana kā kāda konflikta risināšanas pan̄ēmiens. Piezīmes par tiesas sēdes protokolu nav iesniegtas. Senāta ieskatā, pirmās instances tiesas sēdē prokurores izteiktais viedoklis norāda, ka valsts apsūdzības uzturētāja faktiski atzinusi, ka apsūdzētā U. G. nodarījumā nav Krimināllikuma 175. panta ceturtajā daḷā paredzētā noziedzịgā nodarījuma sastāva. Arī pirmās instances tiesa taisỉja attaisnojošu spriedumu, atzīstot, ka U. G. nodarījumā nav Krimināllikuma 175. panta ceturtajā daḷā paredzētā noziedzīgā nodarījuma sastāva [34]. Šis piemērs skaidri parāda iepriekš paustās atziṇas praktisko lietojumu: ja mantkārīgs nolūks un iedzìvošanās uz citu rēḳina nav konstatēta, tad nav arī izdarīts mantkārīgais nodarījums - zādzība.

Mantas nolaupī̌sana vienmēr ir tīšs nodarïjums, ko var izdarīt tikai ar tiešu nodomu, jo vainīgais apzinās, ka rīkojas prettiesiski, pan,emot svešu mantu, viņ̌̌ vēlas šo mantu iegūt un rīkoties ar to pēc saviem ieskatiem. Nolaupīšanas motīvs vienmēr ir mantkārība, jo vainīgais vēlas iegūt mantisku labumu sev vai arī izmantot nolaupìto citos mantkārīgos nolūkos [36, 323].

Vispārēji pieņemta ir atziṇa, ka visi tīšie noziedzīgie nodarījumi ir motivēti. Atstāstot profesora U. Krastina viedokli, jānorāda, ka katru noziedzīgu nodarījumu, kas izdarìts ar nodomu (tîši), determinē noteikts motīvs, kurš vienmēr rodas pirms nodoma. Nodoms rodas un nostiprinās konkrēta motīva ietekmē. Krievijas profesors Anatolijs Kozlovs piedāvā noziedzīga nodarījuma attīstību iedalīt vairākos posmos (sk. 3. att.). 


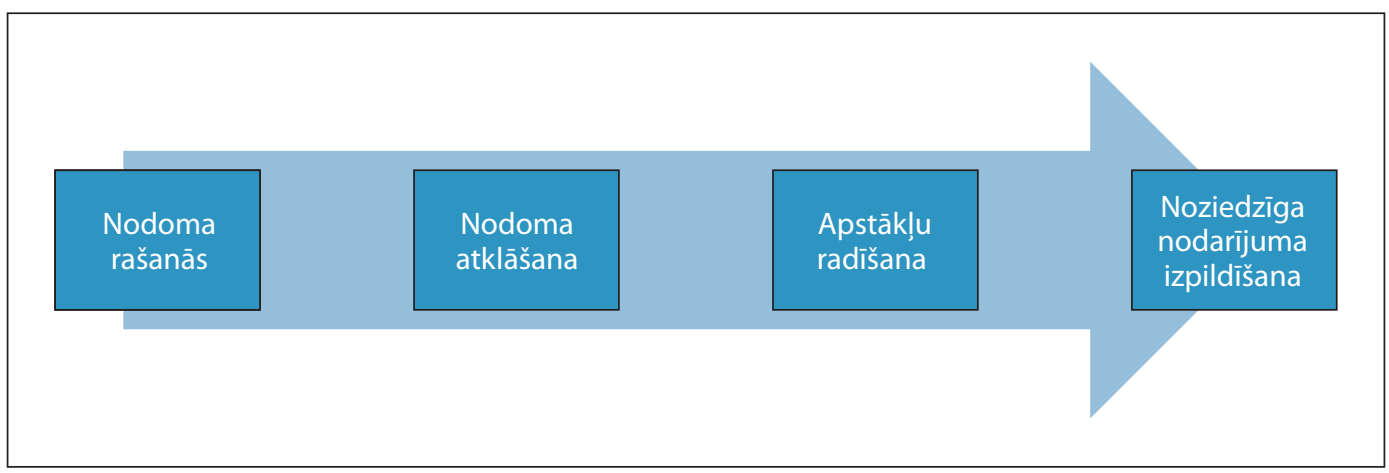

3. attēls. Noziedzīgas rīcības attīstība, Anatolija Kozlova iedalījums [17, 53]

Speciālajā literatūrā atrodams viedoklis, ka diezgan sarežgiiti risināt ir jautājumu par motīvu noziedzīgos nodarījumos aiz neuzmanības. Noziedzīgi nodarījumi aiz neuzmanības var skart vairākas darbības jomas. Piemēram, transportlīdzekḷu ekspluatāciju, celtniecību, darbus, kas saistīti ar iespējamu dabas piesārṇošanu vai bojāšanu.

Daži autori noliedz motīva nozìmi šajos noziedzīgajos nodarỉjumos, bet citi uzskata, ka noziedzīgajos nodarijumos aiz neuzmanības var runāt par uzvedības motivāciju, kas ir cēlonis tam, ka notiek noziedzīgs nodarījums. Vairāki speciālisti, piemēram, P. Dagẹ̦s, T. Krīgers, E. Vorošins, uzskata, ka vairākumā gadījumu noziedzīgiem nodarïjumiem aiz neuzmanības ir apzināts - gribas - raksturs, tātad tie ir motivēti un mērķtiecīgi. Vēl būtu jāatzīmē, ka sabiedriski kaitīgas uzvedības motīvi, piemēram, lielība, pārgalvība, noved pie noziedzīga nodarījuma. Tomēr noziedzīgu nodarījumu aiz neuzmanības gadījumos nav konstatējams noziedzīgs motīvs un mērḳis kā noziedzīgas rīcības iekšējs pamudinājums. Krimināltiesību teorijā ar neuzmanību parasti saprot nepieciešamās rūpības neievērošanu (ignorēšanu).

Nepieciešamās rūpības kritēriji, kas vienlaikus iezīmē ațlautā riska robežas, rodami:

1) normatīvajos aktos, kas reglamentē attiecīgo jomu;

2) privāto organizāciju noteikumos;

3) vispārējos tiesību principos [35].

Motīvs, kā iepriekš minēts, atspoguḷo pamatu, kāpēc konkrētā prettiesiskā rīcība tiek vai bija izdarìta. Motīvs pavada personu, veicot nodarījumu. Noziedzīga nodarījuma motīvi var būt dažādi: mantkārība, savtīgums, atriebība, greizsirdība, strīds, dažādi sadzīviski iemesli, huligāniskas tieksmes, cita noziedzīga nodarījuma slēpšana, karjerisms, sociālās labklājības nodrošināšana, konformisms vai pakḷaušanās ierastajai kārtībai, vienkārša vēlme izpatikt priekšniekam, strādāt, kā "ierasts", kolektīvā, būt kā visi, rasisms, nacionālisms, etniski vai reliğiski, naida, politiskie, seksuālie, narkotisko, psihotropo u. c. vielu iegūšanas, alkoholisko dzērienu iegūšanas, nepareizi izprasta draudzība, pārprastas dienesta intereses, citas personiskās intereses $\mathrm{u}$. tml. Nepilngadīgo personu izdarītajiem nodarījumiem, piemēram, var būt izklaides vai bezdarbības un dīkdienības motīvs. Noziedzịgu nodarījumu var izraisìt vieglprātība vai 
bezatbildība, piemēram, huligāniskas tieksmes izpaužas personas vēlmē izrādīt acīmredzamu necieņu pret sabiedrību un ierastajiem uzvedỉbas noteikumiem, kas nodrošina sabiedrības mieru. Noteikumi tiek demonstratīvi ignorēti, tiek traucēts citu personu normāls darbs, atpūta un sadzìve, kā arī iestāžu, uzṇēmumu un organizāciju darbs. Par šiem jautājumiem daudz atšḳirīgu un interesantu atziṇu sniedz Krievijas profesors Andrejs Zelinskis (А. Ф. Зелинский):

“[..] neesot vajadzība "necienīt", bet pastāv vajadzība pēc cien̦as, prestiža un varas. Tomēr daži cilvēki uzskata, ka nav jārēḳinās ar citu interesēm, un to var nosaukt par huligānismu. Huligānisma motīvs ir tāds pats kā citiem noziedzīgiem nodarījumiem - agresīvs uzbrukums personai, īpašumam, sabiedrībai, sabiedriskai kārtībai un drošîbai, naids, nicinājums, vēlme pašapliecināties. Vardarbība ir varas un pārākuma demonstrācija." [53, 188]

Pareizai noziedzīga nodarījuma subjektīvās puses konstatēšanai un tās atsevišşu pazīmju (vainas, motīva, mērḳa, emocionālā stāvokḷa) noteikšanai ir svarīga nozīme, lai pareizi kvalificētu vainīgā izdarìto nodarījumu [18]. Piemēram, krimināltiesību teorijā atzīts, ka no piesavināšanās atšķiras mantas neatdošana laikā, nelikumīga lietošana, uzglabāšanas noteikumu neievērošana vai mantas pazaudēšana, kas var būt civiltiesisks delikts vai disciplinārs pārkāpums, taču nesatur to l̦aunprātīgo uzticības laušanu, kas ir kriminālās piesavināšanās pamatā. Piesavināšanās ir tikai tad, ja vainīgais izṇēmis svešu mantu nolūkā ar to rīkoties pēc saviem ieskatiem [39, 54]. Piesavināšanās subjektīvā puse izpaužas tieša nodoma veidā, jo vainīgais apzinās savu darbību kaitīgumu, paredz, ka cietušajam nodarīs zaudējumus, un vēlas iedzīvoties no citas personas labuma. Piesavināšanās ir viens no mantas nolaupī̌sanas veidiem, un laupī̌šnas motīvs vienmēr ir mantkārība, bet mērḳis - iegūt materiālu labumu, proti, iedzīvoties uz citas personas rēḳina [22, 20, 33-34].

Tiesu praksē atzìts, ka noziedzīgu nodarījumu pret personas veselību kvalifikācija nereti ir atkarīga no vainīgā rīcības motīviem, tāpēc nodarỉjuma juridiskais izvērtējums, ja motīvs apsūdzībā nav norādīts, var būt kḷūdains. Piemēram, Valmieras rajona tiesa ar 2012. gada 22. marta spriedumu lietā K39-0249/12, krimināllieta Nr. 11130002212, atzīstot A. G. par vainīgu KL 126. panta otrās daḷas 4. punktā paredzētā nozieguma izdarīšanā, konstatēja, ka apsūdzētais, būdams alkohola ietekmē, ne mazāk kā trīs reizes ar rokām sitot cietušajam pa ḳermeni, nodarīja viṇam miesas bojājumus: galvas sasitumu ar zemādas asinsizplūdumiem un nobrāzumiem, krūškurvja sasitumu ar labās puses 6., 10. un 11. ribas lūzumiem. Kāda bija A. G. rīcības motivācija, no apsūdzỉbas nav redzams [51].

Tiesa šādos gadījumos, taisot spriedumu, nevar izpildīt Kriminālprocesa likuma 527. panta pirmajā daḷā ietverto priekšrakstu, ka notiesājoša sprieduma aprakstošajā daḷā jāsniedz pierādìtā noziedzīga nodarījuma apraksts, minot arī apsūdzētā motīvus, jo apsūdzības saturu nosaka prokurors un tiesas tiesības konstatēt citus, no apsūdzỉbas atšḳirīgus apstākḷus ir ierobežotas, jo tiesa nevar šo apsūdzību papildināt, konkretizēt vai kādā dạ̣ā izveidot no jauna, jo tad tiktu pārkāpts procesa pilnvaru nodalīšanas princips [33]. 
Aldona Kipāne. Noziedzīga nodarījuma motīvs kriminolog̣ijas un krimināltiesību kontekstā

\section{Secinājumi}

Noziedzīgam nodarījumam kā indivīda vienotai gribas darbībai ir raksturīgi sarežginiti psihologiskie procesi, kurus ietekmē ne tikai ārējie apstākḷi, bet arī dažādi personas individuālie apstākḷi. Manuprāt, kaut arī personas psihiskā darbība, sākot ar nodoma rašanās brīdi par noziedzīga nodarījuma izdarīšanu līdz pat tā realizācijai, iedalāma atsevišḳos un atšḳirīgos posmos, tomēr tā ir personas psihiskās darbības īstenošanas vienots process, kas rezumējas noziedzīga nodarījuma izdarīšanā. Jāatzīst, ka personas nodoma rašanās ir tieši atkarīga no kāda noteikta motīva un tiek iekḷauta darbībā, kas virzìta uz noteiktu mērḳi. Tas ir mērḳtiecības pamats. Tāpēc uzskatu, ka motīvs un mērḳis ir psihiskās attieksmes nepieciešams komponents.

Domāju, ka motīvs un mērḳis ir subjektīvo pusi veidojoši elementi, jo tie raksturo personas psihi un norises tajā. Cilvēka intelektuālā un gribas darbība ir nesaraujami saistīta ar motivāciju un cilvēka emocionālo pasauli. Par svarīgu šā procesa daḷu kḹst darbības dinamika un attieksme pret to, darbības sociālās jēgas apzināšanās.

Manuprāt, var nodalīt individuālos jeb iekšējos un ārējos personas rīcības motivētājus. Motīvus, kas ietilpst noziedznieka motivācijas jomā, var iedalīt šādās pamatgrupās:

1) sadzīviskie motīvi;

2) sociāli nozīmīgie motīvi;

3) saskarsmes un mijiedarbïbas motīvi;

4) personas attīstības un socializācijas motīvi - sociālās prasmes, kontakti, vērtības.

\section{Crime Motive in Context of Criminological and Criminal Law}

\section{Abstract}

The aim of the research is to study the aspects of motive of crime in the Criminology and Criminal Law. The article presents the analysis of the role of crime motive in crime mechanism.

The author believes that although personal mental activity, starting with the intent of committing a criminal offence until accomplishment of the purpose, is divided into separate and different stages, what matters is a person's mental implementation process result in reality - committing a criminal offence .

Keywords: aim to crime, crime, motive of crime, motivation. 
Aldona Kipāne. Noziedzīga nodarījuma motīvs kriminolog̣ijas un krimināltiesību kontekstā

\section{Literatūra}

1. Bārtulis, J. Nevis izstumt, bet palìdzēt laboties. Iegūts no: http://www.lvportals.lv/print. php?id=212881 [sk. 30.03.2016.].

2. Bel̦ska, A. Noziedzìga nodarījuma izpratne Latvijas un Amerikas Savienoto Valstu krimināltiesībās. Promocijas darbs. Rīga: Latvijas Universitāte, 2013.

3. Belskii, V. Iu., Kravchenko, A. I., Kurganov, S. I. Sociologiia dlia iuristov: Uchebnoe posobie dlia vuzov. Moskva:Zakon i pravo, 2011. (Бельский, В. Ю., Кравченко, А. И., Курганов, С. И. Социология для юристов: Учебное пособие для вузов. Москва: Закон и право, 2011).

4. Bilalov, R. K. Kriminologicheskaia kharakteristika lichnosti prestupnika, sovershaiushego nasilstvennie polovie prestupleniia protiv nesovershennoletnikh. Novyi Iuridicheskii Zhurnal. 2012, 3. (Бималов, Р. К. Криминологическая характеристика мичности преступника, совершающего насицьственные половые преступцения против несовершеннолетних. Новый юридический журнал. 2012, 3).

5. Bolshoi iuridicheskii slovar. Sukharev, A. Ia., Krutskikh, V. E., Sukhareva, A. Ia. Moskva: Infra-M, 2003. (Большой юридический словарь. Сухарев, А. Я., Крутских, В. Е., Сухарева, А. Я. Москва: Инфра-М, 2003).

6. Bolshoi iuridicheskii slovar. Moskva: Prospekt A. V. Malko, 2009. (Большой юридчческий словарь. Москва: Проспект. А. В. Малько, 2009).

7. Chastnaia kriminologiia. Otv. red. prof. A. Shestakov. Sankt-Peterburg: Iuridicheskii centr Press, 2007. (Частная криминология. Отв. реА. проф. А. Шестаков. Санкт-Петербург: Юридический центр Пресс, 2007).

8. Filimonov, V. D. Norma ugolovnogo prava. Sankt-Peterburg: Izdatelstvo R. Aslanova Iuridicheskii centr Press, 2004. (Филимонов, В. А. Норма уголовного права. СПб.: Издательство Р. Асланова Юридический центр Пресс, 2004).

9. Flowers, R. B. Sex Crimes: Perpetrators, Predators, Prostitutes, and Victims. Charles Thomas Publishers, Ltd, 2006.

10. Friedrich, C. J. The pathology of Politics: Violence, Betrayl, Corruption, Secrecy, and propoganda. New York: Harper \& Row, 1972.

11. Gabrielyan, A. Eitanāzijas fenomens krimināltiesiskajā, kriminologiskajā un medicīniski biologiskajā aspektā. Promocijas darbs. Rīga: Rīgas Stradiña universitāte, 2014.

12. Handbook of Sexual Violence, J. M. Brown, S. L. Walklate (Eds.). Routledge, 2011.

13. Judins, A. Apstākḷi, kas izslēdz kriminālatbildību. Rīga: SIA "Biznesa augstskola Turība”, 2006.

14. Judins, A. Krimināltiesību jēdzienu skaidrojošā vārdnīca. Rīga: Latvijas Policijas akadēmija, 1998.

15. Klarks, R. V., Eks, Dž. E. Noziedzības analizze 60 soḷos. Rīga: Valsts policija, 2011.

16. Korupcijas novēršanas un apkarošanas pamatnostādnes 2015.-2020. gadam. Iegūts no: http://likumi.lv/ta/id/275394-par-korupcijas-noversanas-un-apkarosanas-pamatnostadnem2015-2020-gadam [sk. 30.03.2016.].

17. Kozlov, A. P. Uchenie o stadiiakh prestupleniia. Sankt-Peterburg: Izdatelstvo Iuridicheskii centr Press, 2002. (Козмов, А. П. Учение о стадиях преступления. - СПб.: Издательство Юридический центр Пресс, 2002).

18. Krastin̦š, U. Noziedzīga nodarījuma sastāvs un nodarījuma kvalifikācija. Teorētiskie aspekti. Rìga: Tiesu namu ag̀entūra, 2014.

19. Krastinš̌, U. Noziedzīgs nodarījums. Rīga: Tiesu namu agentūra, 2000. 
Aldona Kipāne. Noziedzīga nodarïjuma motīvs kriminolog̣ijas un krimināltiesību kontekstā

20. Krastiṇš, U., Liholaja, V. Krimināllikuma komentāri: Pirmā daḷa (I-VII nodal̦a). Rīga: Tiesu namu aǵentūra, 2015.

21. Krastiņš, U., Liholaja, V., Niedre, A. Krimināllikuma zinātniski praktiskais komentārs 2. Sevišḳā daḷ. Rīga: AFS, 2007.

22. Krastiṇš, U., Liholaja V., Niedre, A. Krimināllikuma zinātniski praktiskais komentārs 3. Sevišșāa dal̦a. Rìga: AFS, 2007.

23. Krastiṇš, U., Liholaja, V., Niedre, A. Krimināltiesības. Vispārīgā daḷa. Trešais papildinātais izdevums. Rīga: Tiesu namu aǵentūra, 2008.

24. Kriminolog̣ija. Mācību grāmata. Zin. red. K,ipēna K., Vilks A. Rīga: Nordik, 2004.

25. Kriminologiia, Uchebnik. Pod red. prof. N. F. Kuznecovoi, prof. V. V. Luneeva. Moskva, 2004. (Криминология: Учебник. ПоА. реА. проф. Н. Ф. Кузнецовой, проф. В. В. Аунеева. Москва, 2004).

26. Kriminologiia. Uchebnik dlia vuzov. Pod obshchei redakciei professora A. I. Dolgovoi. Moskva: Izdatelstvo NORMA, 2001. (Криминология. Учебник для вузов. ПоА общей реАакцией профессора А. И. Аолговой. Москва: ИзАатемьство НОРМА, 2001).

27. Kristapsone, S. Noziedzība un to noteicošie sociāli ekonomiskie faktori Latvijā 90. gados. Promocijas darbs. Rīga: Latvijas Universitāte, 2003.

28. Kriviņš, A. Korupcijas novēršana un apkarošana publisko iepirkumu jomā. Rìga: SIA “Izdevniecība "Drukātava"”, 2015.

29. Kronberga, I. Kas ir noziedzības novēršana? Iegūts no: http://providus.lv/article/kas-ir-noziedzibas-noversana [sk. 30.03.2016.].

30. Latgales apgabaltiesas Krimināllietu tiesas kolēgijas 2015. gada 16. aprīla spriedums (lietas Nr. 11320041514, lietas arhīva Nr. KA03-0117-15).

31. Latvijas Republikas Augstākās tiesas Krimināllietu departaments. Tiesu prakse krimināllietās pēc Krimināllikuma 317. panta 2. daḷas, 318. panta 2. dal̦as un 319. panta 2. dal̦as. Iegūts no: www.at.gov.lv/lv/judikatura/tiesu-prakses-apkopojumi/kriminaltiesibas/ [sk. 30.03.2016.].

32. Latvijas Republikas Augstākās tiesas 2015. gada 29. jūnija lēmums (lietas Nr. 11087220308, lietas arhīva Nr. SKK-0142-15).

33. Latvijas Republikas Augstākās tiesas Senāta Krimināllietu departamenta 2012. gada 4. jūnija lēmums lietā Nr. SKK-8/2012, krimināllieta Nr. 15890002505.

34. Latvijas Republikas Augstākās tiesas Senāta Krimināllietu departamenta 2013. gada 25. janvāra lēmums lietā SKK-6/2013, krimināllieta Nr. 11091207011.

35. Leja, M. Noziedzīga nodarījuma izdarīšana aiz neuzmanības. Jurista Vārds. 2011. gada 14. jūnijs, 24 (671).

36. Liholaja, V. Noziedzīgu nodarījumu kvalifikācija: Likums. Teorija. Prakse. Otrais papildinātais izdevums. Rīga: Tiesu namu aǵentūra, 2007.

37. Lukasheva, E. A. Motivi povedeniia cheloveka v pravovoj sfere. SGP, 1972. (Аукашева, Е. А. Мотивы поведения человека в правовой сқере. СГП, 1972).

38. Lunejev, V. V. Motivaciia prestupnogo povedeniia. Moskva: Nauka, 1991. (Аунеев, В. В. Мотивация преступного поведения. Москва: Наука, 1991).

39. Mežulis, D. Krimināltiesības shēmās: Vispārīgā daḷa. Rīga: Turība, 2013.

40. Mits, M. Par iecietības veicināšanu Latvijā: konferences kopsavilkums. Jurista Vārds. 2014. gada 18. marts, 11 (813). 
41. Oganesian, B. L. Poniatie motiva korysti v teorii ugolovnogo prava i ego otrazhenie v UK RF. Molodoj Uchonij. 2013, 7. (Оганесян, Б. А. Понятие мотива корысти в теории уголовного права и его отражение в УК РФ. Молодой Ученый. 2013, 7. Iegūts no: http://www.moluch. ru/archive/54/7445/ [sk. 31.03.2016.].

42. Par krimināllikumu piemērošanu lietās par tīšàm slepkavībām: Latvijas Republikas Augstākās tiesas plēnuma lēmumu krājums. Rīga: Latvijas Policijas akadēmija, 2002.

43. Petin, I. A. Mehanizm prestupnogo nasiliia. Sankt-Peterburg: Iuridicheskii centr Press, 2002. (Петин, И. А. Механизм преступного насимия. СПб.: Юридический центр Пресс, 2004). 44. Psihologijas vārdnīca. G. Breslava red. Rīga: Mācību grāmata, 1999.

45. Roja, Ž., Roja I., Kalı kis, H. Stress un vardarbība darbā. Ko darīt? Rīga: Gutenbergs Druka, 2016.

46. Semenkova, V., Miḳelsons, U. Drošǐbas psihologija. Iegūts no: http://www.eksperts.gold.lv/ Drosibas_psihologija.pdf [sk. 31.03.2016.].

47. Sitkovskaia, O. D. Motivaciia agresivnogo povedeniia nesovershennoletnikh prestupnikov. Nasilie, agressiia, zhestokost. Kriminalno-psikhologicheskoe issledovanie. Moskva, 1990. (Ситковская, О. А. Мотивация агрессивного поведения несовершеннолетних преступников. Насилие, агрессия, жестокость. Криминально-исихологическое исследование. Москва, 1990).

48. Skliarov, S. Vina i motivy prestupnogo povedeniia. Sankt-Peterburg: Iuridicheskii centr Press, 2004. (Скмяров, С. Вина и мотивы преступного поведения. СПб.: ЮриАический центр Пресс, 2004).

49. Stumbiṇa, E.., Birkavs, V., Niedre, A. Kriminoloǵija. Rīga: Zvaigzne, 1981.

50. Svešvārdu vārdnīca. Rīga: Avots, 2008.

51. Tiesu prakse noziedzīgu nodarījumu kvalificēšanā, ja lieta izskatīta bez pierādījumu pārbaudes. Latvijas Republikas Augstākās tiesas Senāta Krimināllietu departaments, 2013.

52. Vorobjovs, A. Sociālā psiholoǵija. Rīga: Izglīîibas soḷi, 2002.

53. Zelinskii, A. F. Kriminalnaia psihologiia. Nauchno prakticheskoe izdanie. Kiev: Iurinkom Inter, 1999. (Зелинский, А. Ф. Криминальная психология. Научно-практическое издание. Киев: Юринком Интер, 1999).

54. Tararukhin, S. A. Ustanovlenie motiva i kvalifikaciia prestuplenii. Kiev, 1977. (Тарарухин, С. А. Установление мотива и квамификация преступлений. Киев: 1977).

55. Ugolovnoe pravo Rossii. Chast obshchaia. Uchebnik. Moskva: Volters Kliver, 2005. (Уголовное право России. Часть Общая. Үчебник. Москва: Волтерс Кмивер, 2005.). 